\title{
"Polícia, quando quer, faz!": análise da estrutura de governança do Pacto pela Vida, de Pernam- buco
}

\author{
Andréia de Oliveira Macêdo \\ Orientador: Arthur Trindade Maranhão Costa \\ Dissertação de Mestrado \\ Data da defesa: 26.04.2012
}

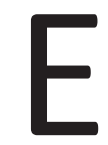

ste estudo pretendeu apreender e analisar os mecanismos e instrumentos formais de articulação que conferem capacidade de governança à política pública de redução dos homicídios em Pernambuco, denominada "Pacto pela Vida". Nesse sentido, buscou-se problematizar em que medida os desafios impostos à necessidade de coordenação de ações para controle e redução dos chamados "Crimes Violentos Letais e Intencionais" do Estado configuraram uma mudança, em termos paradigmáticos, na gestão local da segurança pública.

Os resultados apontaram que a política de segurança do estado de Pernambuco assume a tentativa de conciliação entre as duas estratégias de controle criminal, explicadas por Garland (2008): "estratégia de segregação punitiva" e "parcerias preventivas". Para tanto, foram criados procedimentos e instaladas estruturas de administração pública, voltadas ao campo do controle e da justiça criminal, afeitas à filosofia da gestão por resultados. Também foram absorvidas inovações desenvolvidas no modelo Compstat de Nova York, configurando um exemplo de mudança institucional que Powell e Dimaggio (1991) classificariam como "isomorfismo mimético". A formatação do modelo Compstat, aplicado à realidade da segurança pública pernambucana, alterou a forma procedimental das polícias e tornou necessária a discussão coletiva de soluções e respostas aos problemas focais estabelecidos pela política. Entretanto, é possível afirmar que houve reforço institucional e valorização das estratégias de controle pautadas na ação policial, mobilizando mecanismos e instrumentos do que o texto norteador do "Pacto pela Vida" convencionou chamar de "repressão qualificada", ou, em outros termos, de controle por meio de atuação policial repressiva.

Palavras-chave: Controle do Crime, Redes de Políticas Públicas, Governança, Segurança Pública. 